\title{
LIGHT AND ELECTRON MICROSCOPE STUDIES ON LIPID STAINED BY MALACHITE GREEN IN THE MALE REPRODUCTIVE TRACT OF THE RABBIT, HAMSTER AND MONGOOSE
}

\author{
J. M. CUMMINS,* M. H. BERNSTEIN† AND R. J. TEICHMAN \\ Department of Anatomy and Reproductive Biology, \\ University of Hawaii School of Medicine, \\ 1960 East-West Road, Honolulu, Hawaii 96822, U.S.A.
}

(Received 3rd December 1973)

\begin{abstract}
Summary. Reproductive tracts from male rabbits, hamsters and mongooses were fixed in glutaraldehyde containing malachite green. The technique stains phospholipids, glycolipids, fatty acids and cholesterol, and is known to retain a lipid within spermatozoa which is lost during conventional fixation. In rabbit spermatozoa, the lipid has been identified as choline plasmalogen, which accumulates in the postacrosomal region of the head during epididymal transit. In testes, malachite green stained Leydig cell granules and cytoplasmic inclusions in maturing spermatids. Large quantities of stained material were evident in the epididymides and accessory glands, including basal cell lysosomes which increased in size and frequency after castration, supranuclear cytosome-like bodies, material associated with smooth endoplasmic reticulum, vesicles distributed throughout the principal cells of the epithelium and material around the stereocilia of the epididymis. Amounts of material in the epididymal lumen increased markedly from caput to cauda, indicating active secretion.
\end{abstract}

\section{INTRODUCTION}

Teichman, Fujimoto \& Yanagimachi (1972) found that mammalian spermatozoa fixed in glutaraldehyde containing malachite green or pyronine retained highly osmiophilic material which was lost during conventional fixation. Spot tests and thin-layer chromatography aimed at determining the staining affinity of malachite green showed that it binds strongly with fatty acids, glycolipids, phospholipids and cholesterol but has no affinity for glycerylphosphorylcholine (GPC) (Teichman, Takei \& Cummins, 1974). The 'malachite-green-affinity' (MGA)-material in rabbit spermatozoa has been shown to consist largely of choline plasmalogen (Teichman, Cummins \& Takei, 1974a).

\footnotetext{
* Present address: Zoology Department, Victoria University of Wellington, Wellington, New Zealand.

$\dagger$ Present address: Department of Anatomy, Wayne State University School of Medicine, Detroit, Michigan, U.S.A.
} 
The MGA material accumulates in rabbit spermatozoa during the final stages of maturation in the epididymis and there is evidence suggesting that it may function as an energy source for the spermatozoa in the female tract (Cummins \& Teichman, 1974). The present paper describes studies on malachite green staining of the male reproductive tract, and is the first published account of the use of this stain-fixative mixture for studying lipids in tissues other than spermatozoa.

\section{MATERIALS AND METHODS}

This study is based upon tissues removed from eight rabbits of mixed breed, eight Syrian hamsters and two mongooses (Herpestes auropunctatus), all of which were mature males maintained under controlled indoor conditions. Small pieces of tissue from the reproductive tracts were fixed at $5^{\circ} \mathrm{C}$ in $3 \%$ glutaraldehyde, buffered with $0.067 \mathrm{M}$-sodium cacodylate ( $\mathrm{pH} \mathrm{6.8)}$ and containing $0.1 \%$ malachite green (Allied Chemicals). After anaesthetizing with Nembutal, the mongooses and three of the rabbits were perfused through the aorta with the stain-fixative mixture for $30 \mathrm{~min}$; otherwise, tissues were fixed immediately after killing the animals by cervical dislocation. Control pieces of tissue were fixed in buffered glutaraldehyde without malachite green. Fixation was carried out for 6 to $12 \mathrm{hr}$ at $5^{\circ} \mathrm{C}$, after which the tissues were washed in buffer and postfixed for an additional $12 \mathrm{hr}$ at $5^{\circ} \mathrm{C}$ in buffered $1 \%$ osmium tetroxide. The tissues were dehydrated in a graded series of ethanol, and embedded in Epon 812; representative tissues from one of the mongooses were also embedded in paraffin wax, and subjected to routine histological sectioning and staining. Ejaculated rabbit spermatozoa were fixed according to Teichman et al. (1972). Plastic sections were cut using a Reichert ultramicrotome. Thick sections $(0.5$ to $3 \mu \mathrm{m})$ were mounted on glass slides, stained with Richardson's stain, and examined using a Zeiss Photomicroscope II; thin sections were mounted on copper grids and examined without further staining in an RCA $4 \mathrm{E}$ electron microscope.

The emphasis of this study is upon normal morphology. As part of a preliminary study on the effect of androgen withdrawal upon malachite green staining of the male reproductive system, however, two of the rabbits and four of the hamsters were subjected to bilateral testicular ischaemia, which caused effective castration. This operation consisted of passing a double ligature around the vascular pedicle containing the testicular artery and vein at its point of entry into the testis and below the epididymis. The ligature included the efferent ductules connecting testis and epididymis and resulted in isolation and ischaemia of the testis, which remained as a necrotic mass preventing the scrotum from contracting and from forcing the epididymis into the inguinal canal. As controls, one rabbit and two hamsters were subjected to simple ligation of the vasa efferentia, thus cutting off the sperm supply to the epididymis without removing the testis as a source of circulating androgens.

\section{RESULTS}

\section{Light microscopy}

Localizations of MGA material appeared as dark masses when examined 
using bright-field optics (Pl. 4, Fig. 14), but in thick sections they could be confused with other osmiophilic bodies not stained by malachite green. The material was most readily visualized as bright yellow or orange when using positive phase-contrast microscopy without filters (PI. 1, Figs 2 to 9). The optimum Epon-embedded section thickness was found to lie between 1.5 and $2.5 \mu \mathrm{m}$; in sections thicker than this, other osmiophilic material also tended to cause a colour shift, and could not readily be distinguished from the MGA material itself (Pl. 1, Fig. 6).

\section{Electron microscopy}

The extremely dense MGA localizations were easily distinguished from simple osmiophilia in electron micrographs of unstained sections. The material varied in morphology; most commonly, it was homogenous and apparently membrane-limited, but occasionally membranous whorls resembling myelin figures were observed (Pl. 5, Fig. 17). An unusual structure consisting of strands of MGA material embedded in a homogeneous, moderately electrondense matrix (Pl. 3, Fig. 13) was also observed to lie between the nucleus and Golgi region of the epididymal columnar cells.

Testis

Localizations of MGA material were observed in interstitial tissue and germinal epithelium (Pl. 2, Fig. 11). In the Leydig cells, the localizations were round, and corresponded to osmiophilic lipid droplets with a slightly irregular outline (Pl. 2, Fig. 10), which were also in control sections. In the germinal epithelium, the material was found as smoothly rounded masses in the cytoplasm of maturing spermatids, on the luminal side of the nucleus (Pl. 2, Fig. 12).

\section{Epididymis}

The gross anatomy and ultrastructure of the epididymis has been recently reviewed by Hamilton (1972). In the present paper, the conventional terms, 'caput', 'corpus' and 'cauda' are employed for convenience though, as Glover \& Nicander (1971) have pointed out, this terminology may be misleading for some species. The epididymis of the mongoose has not been previously described, but like the rest of the male reproductive system (Pearson \& Baldwin, 1953), it is presumably typical of a small carnivore; that of the hamster has recently been described by Nicander \& Glover (1973).

Although MGA material appeared throughout the epididymis of the three species studied here, there were minor variations in total amount between individuals. The most striking observation by light microscopy was of increases in the amount of MGA material in the lumen in progressively more distal regions of the duct (Tables 1 and 2), and this was paralleled by increases in the size and frequency of localizations in the supranuclear and apical regions of the principal cells of the epithelium. The MGA material in the lumen appeared both free, and within anuclear cytoplasmic bodies (Pl. 1, Fig. 9). Large amounts of material were also enmeshed in the stereocilia lining the duct (Pl. 4, Fig. 14). The material was also observed in basal cells at all levels of the epididymides, and it was frequently associated with lysosome-like masses of 
other osmiophilic material which were not stained by malachite green, and which were also visible in control tissues.

Electron microscopy of the tissues revealed that the appearance of the MGA material in the epididymis could be classified into a number of morphological

\section{EXPLANATION OF PLATES 1 TO 3}

\section{PLATE 1}

Figs 1 to 9 . All photomicrographs are of 1.5 to $2.5 \mu \mathrm{m}$ Epon-embedded sections, photographed using positive phase-contrast optics.

Fic. 1. Rabbit distal caput epididymidis control. This material was fixed in glutaraldehyde without malachite green. $\times 308$.

FIG. 2. Rabbit distal caput epididymidis. This tissue was from a region immediately adjacent to that shown in Fig. 1, but was fixed in glutaraldehyde containing malachite green. Light-yellow MGA localizations are visible in the smooth muscle, basement membrane, and basal cells, as well as in the columnar epithelium. Localizations are especially prevalent in sub-nuclear and apical positions. $\times 308$.

FIG. 3. Rabbit distal caput epididymidis. Highly refractile, yellow-orange MGA localizations are apparent in the basal cells, in the supranuclear regions of the columnar cells, and in the lumen (arrowed). $\times 771$.

FIG. 4. Rabbit proximal corpus epididymidis. This region contains relatively little MGA material in apical regions of the columnar cells. Other osmiophilic material, not stained by malachite green, appears as dark granules. $\times 771$. Insert: Ejaculated rabbit spermatozoon showing MGA material in the postacrosomal region of the head. Spermatozoa do not exhibit the material until they reach the corpus epididymidis.

Fig. 5. Hamster caput epididymidis. The MGA material is evident throughout the epithelium. $\times 771$.

FIG. 6. Hamster seminal vesicle. Much MGA material is evident as bright yellow accretions in the lumen as well as in the epithelium. Other osmiophilic material not stained by malachite green appears olive-green to light brown (arrowed) in this $2-\mu \mathrm{m}$ section; in sections thicker than $2.5 \mu \mathrm{m}$, it is not possible to distinguish the two types of material. $\times 308$.

Fig. 7. Rabbit initial segment, 7-day castrate. Castration by bilateral testicular ischaemia (see text) causes large lysosome-like masses (arrowed) of black osmiophilic material, interspersed with yellow refractile MGA material, to appear in the basal and columnar cells. Other MGA localizations are evident, as is cellular débris in the lumen of the duct. $\times 308$.

Fig. 8. Rabbit initial segment, 14-day castrate. After 2 weeks of androgen deprivation, the epithelium is flattened and shows various degrees of loss of stereocilia. Large masses of osmiophilic material are apparent, but there is little MGA material. $\times 771$.

Fig. 9. Hamster cauda epididymidis, 7-day castrate. The epithelium appears to be little affected, but note the large cytoplasmic body containing MGA material in the lumen (arrowed). $\times 771$.

\section{PLATE 2}

Fig. 10. Mongoose testis interstitial tissue, unstained. Large, dense, irregularly outlined masses of MGA material (arrowed), apparently not bounded by membrane, are visible in the Leydig cells $(\mathrm{L}) . \times 12,000$.

FIG. 11. Mongoose testis showing localizations of MGA material (arrowed) in spermatid cytoplasm and in Leydig cells. $\times 320$.

FIG. 12. Unstained mongoose testis. Roughly spherical MGA localizations (arrowed) are distributed throughout the cytoplasm of maturing spermatids (S), on the luminal side of the nucleus. $\times 5000$.

\section{PLATE 3}

FIG. 13. Sagittal section through the columnar epithelium of mongoose proximal caput epididymidis, unstained. Dense, irregularly outlined masses of MGA material are visible throughout the cytoplasm being especially large close to the basement membrane (BM). Localizations of MGA material are also visible as spicules, or strands, embedded in an amorphous, electron-dense matrix (arrowed) between the nucleus (N) and Golgi apparatus. The lumen of the duct is evident $(L) . \times 4000$. 
PIATE 1
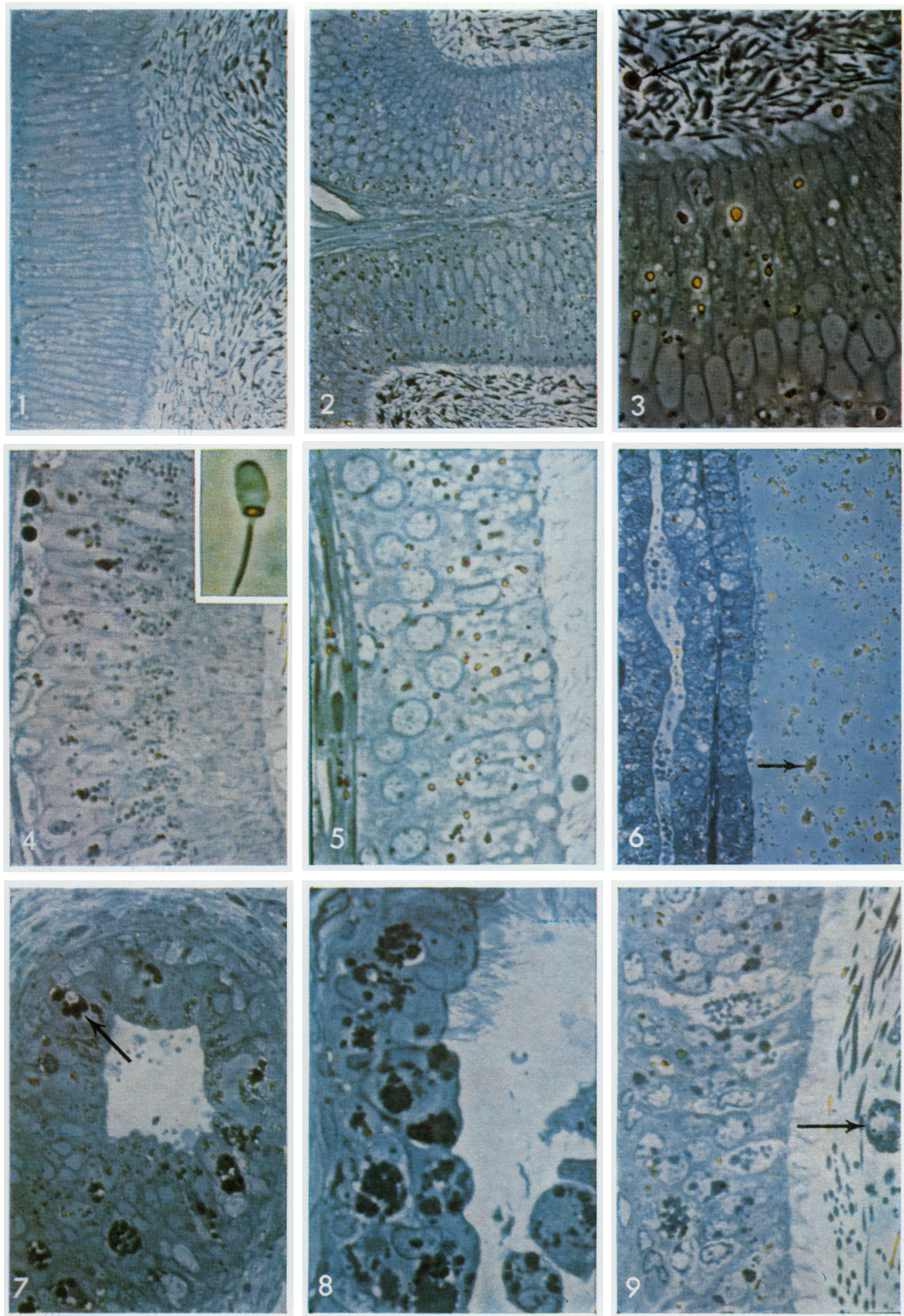


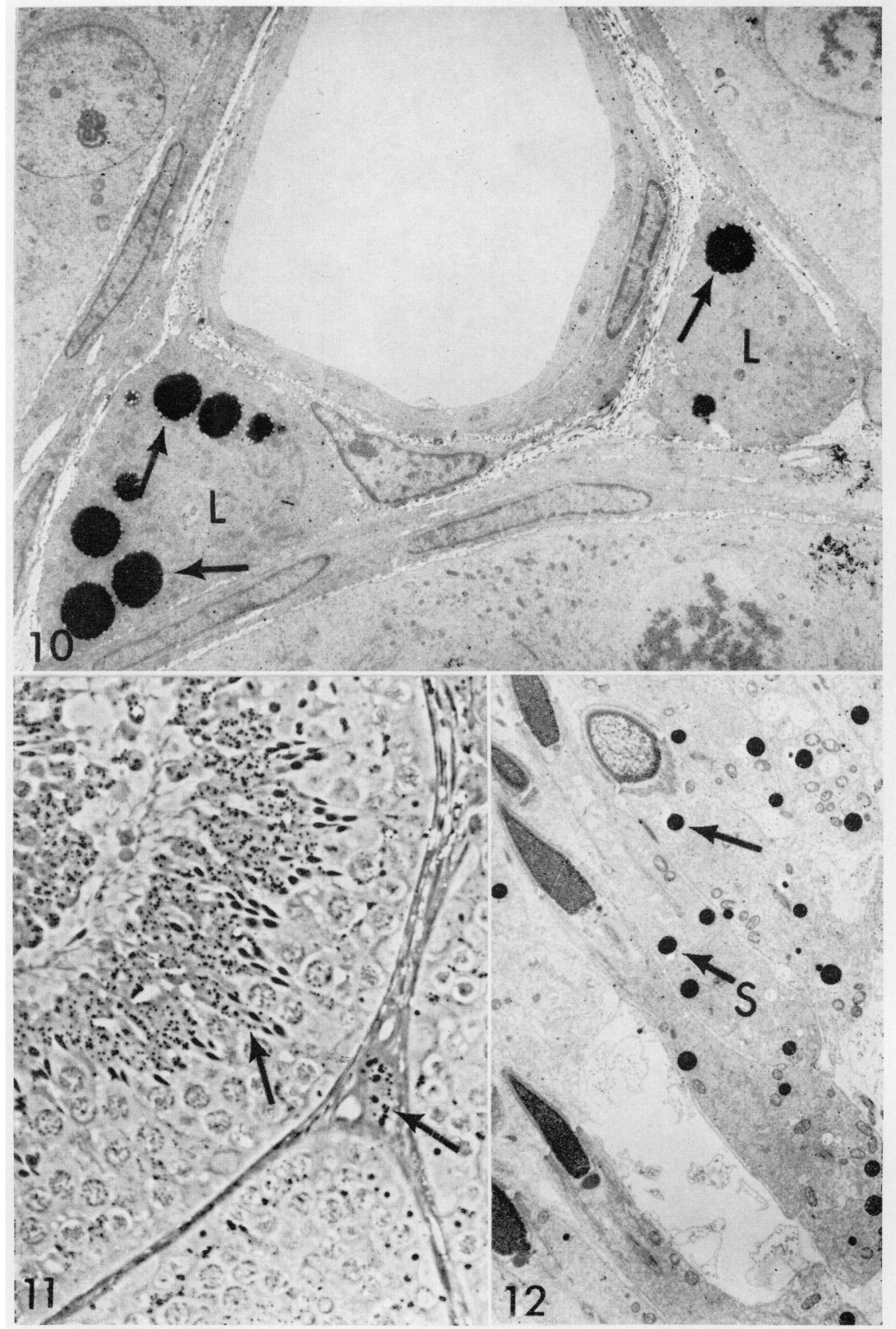


PLATE 3

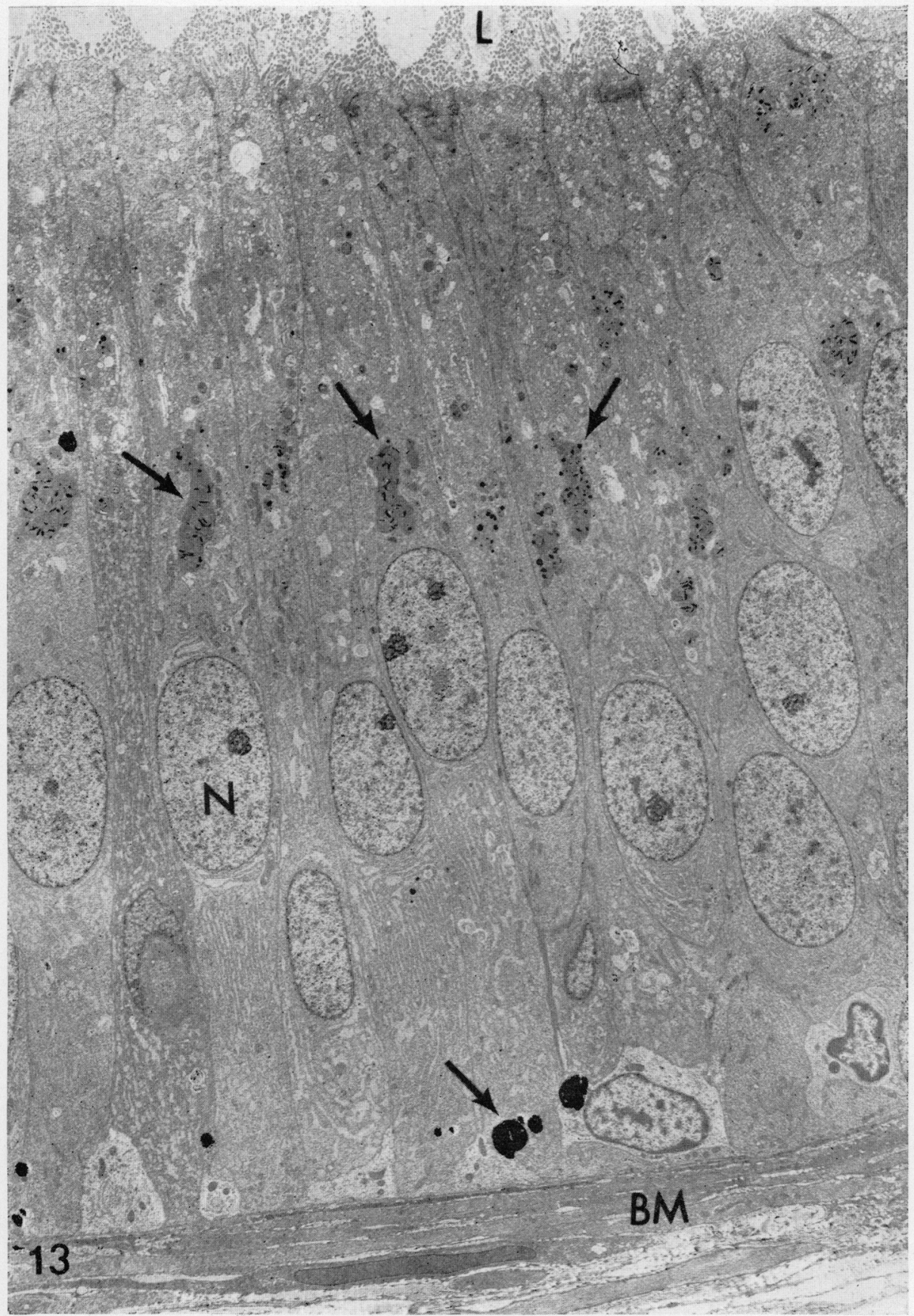




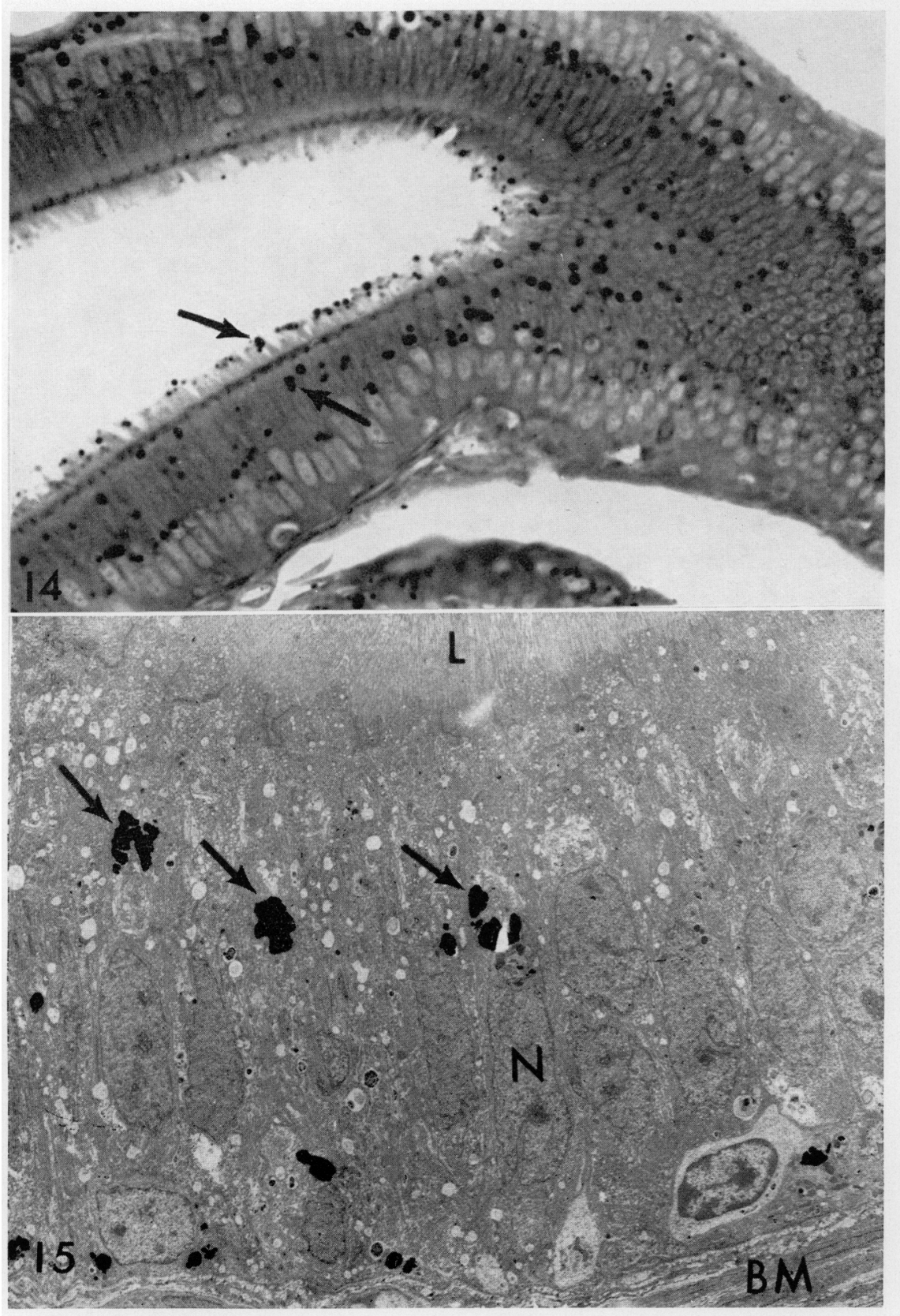


PIATE 3

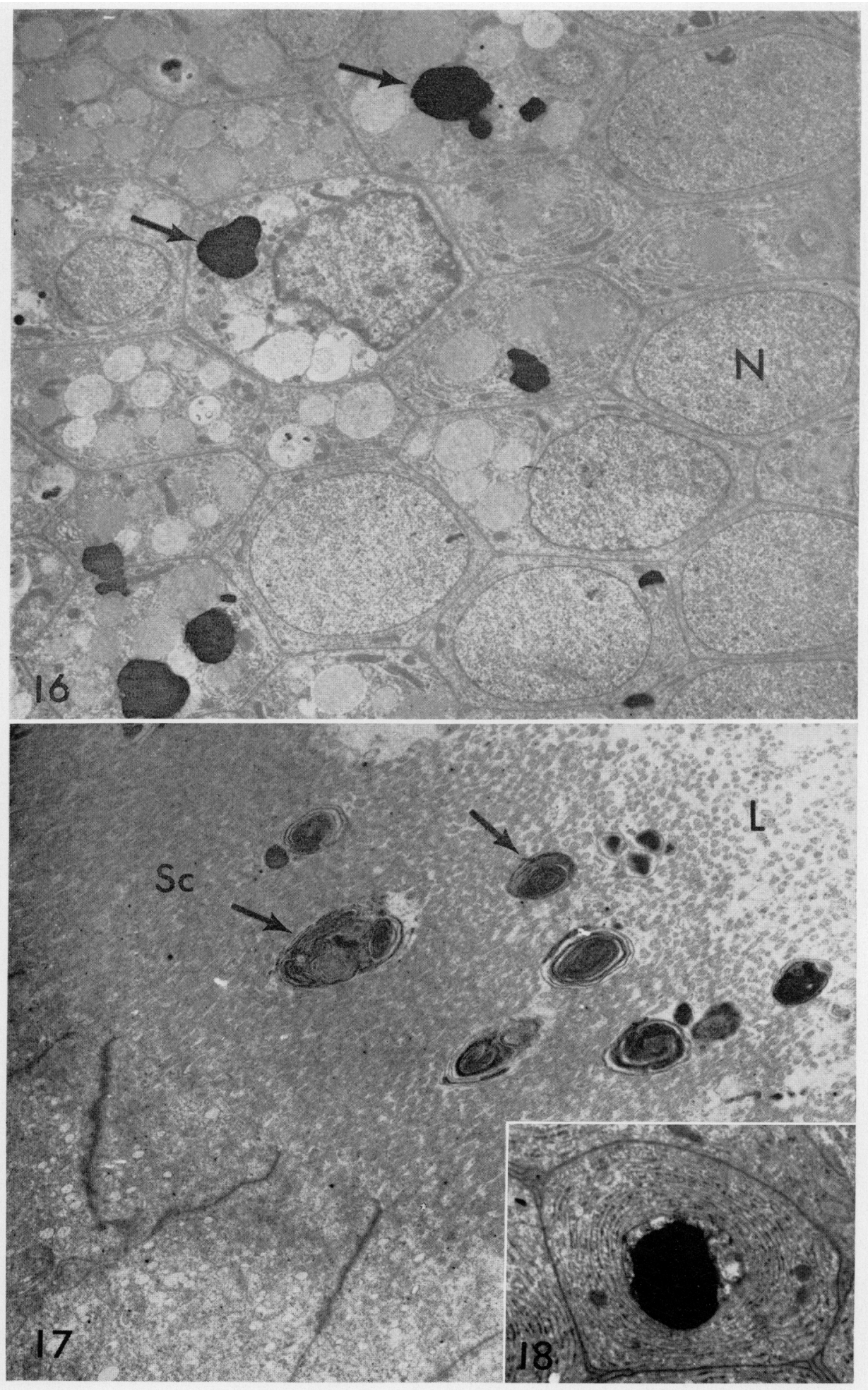


PLATE 6

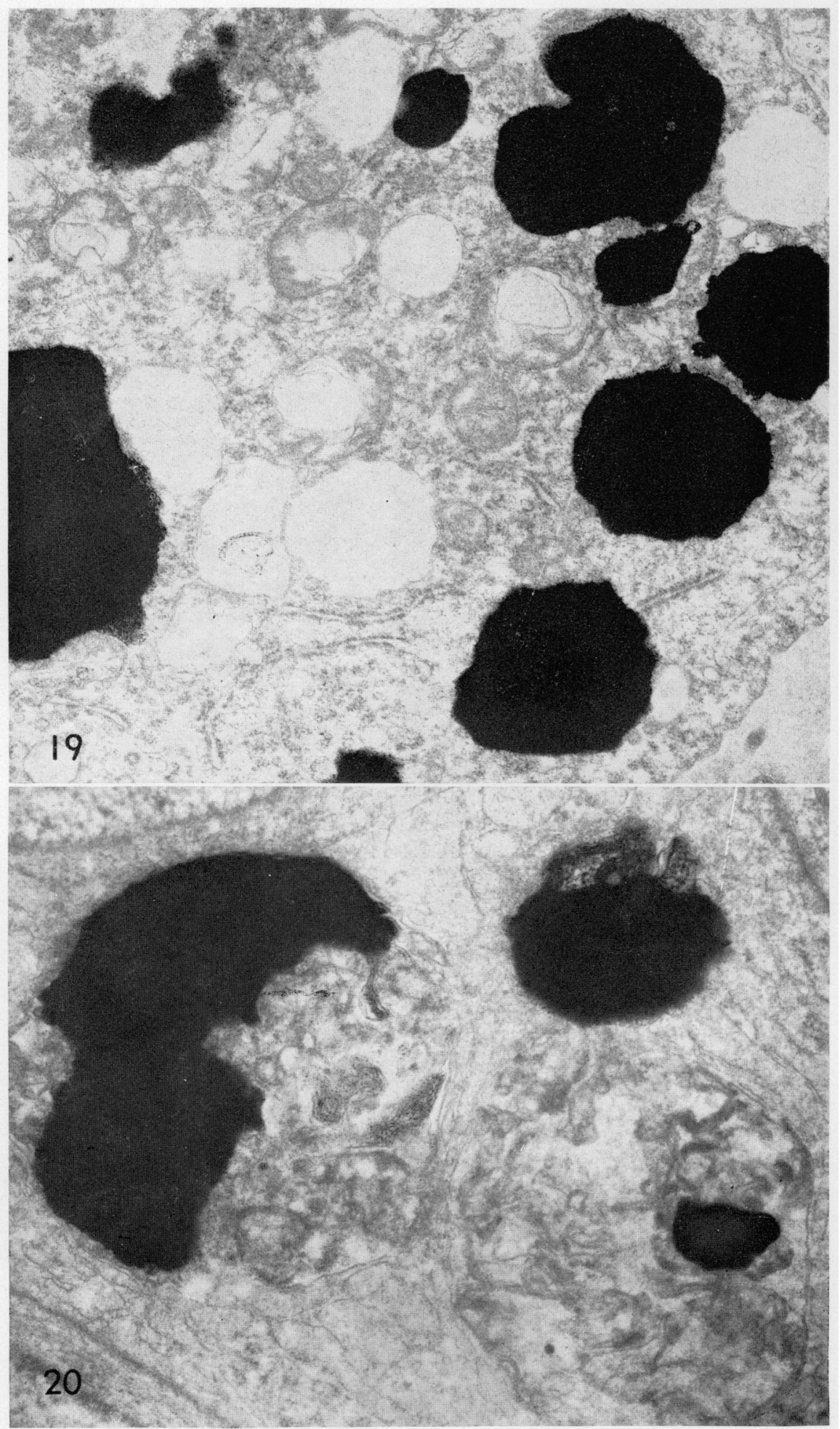


Table 1. Relative amounts of MGA material in the normal rabbit epididymis

\begin{tabular}{l|c|c|c|c|c}
\hline \multicolumn{1}{c|}{ Region* } & $\begin{array}{c}\text { Basement } \\
\text { membrane }\end{array}$ & $\begin{array}{c}\text { Basal } \\
\text { cells }\end{array}$ & Subnuclear & Supranuclear & Luminal \\
\hline Initial segment (1) & + & ++ & ++ & ++ & ++ \\
Proximal caput (2) & + & +++ & +++ & +++ & ++ \\
Distal caput (3 to 5) & ++ & +++ & ++ & +++ & ++ \\
Proximal corpus (6) & ++ & +++ & ++ & ++ & ++ \\
Distal corpus (7) & ++ & +++ & +++ & +++ & ++ \\
Cauda (8) & ++ & +++ & +++ & +++ & +++ \\
Ductus deferens & +++ & +++ & +++ & +++ & +++ \\
\hline
\end{tabular}

* Numbers in parentheses are those assigned to the regions by Nicander (1956).

Table 2. Relative amounts of MGA material in the normal hamster epididymis

\begin{tabular}{l|c|c|c|c|c}
\hline \multicolumn{1}{c|}{ Region } & $\begin{array}{c}\text { Basement } \\
\text { membrane }\end{array}$ & $\begin{array}{c}\text { Basal } \\
\text { cells }\end{array}$ & Subnuclear & Supranuclear & Luminal \\
\hline Initial segment & + & ++ & ++ & ++ & + \\
Caput & + & +++ & ++ & ++ & + \\
Proximal corpus & + & +++ & ++ & +++ & + \\
Distal corpus & + & +++ & ++ & +++ & ++ \\
Cauda & + & +++ & ++ & +++ & +++ \\
Ductus deferens & + & ++ & ++ & +++ & +++ \\
\hline
\end{tabular}

\section{EXPLANATION OF PLATES 4 TO 6}

\section{PLATE 4}

Fig. 14. Corpus epididymidis of mongoose. The luminal contents were lost during processing, but note the large masses of dark MGA material (arrowed) enmeshed in the stereocilia as well as in supranuclear regions of the columnar cells. $\times 500$.

FIG. 15. Unstained rabbit cauda epididymidis. Localizations of MGA material (arrowed) are evident as large, irregular masses in the supranuclear and basal regions of the columnar cells, as well as in the basal cells (lower right). Some malachite green staining is also associated with vacuoles containing myelinoid whorls of membrane. $L=l$ lumen, $\mathrm{N}=$ nucleus, $\mathrm{BM}=$ basement membrane. $\times 2600$.

\section{PLATE 5}

FIg. 16. Unstained distal caput epididymidis of rabbit. Large accumulations of MGA material (arrowed) are interspersed with electron-dense and clear vacuoles, as well as multivesicular bodies. $\mathrm{N}=$ nucleus. $\times 6000$.

FIG. 17. Unstained mongoose corpus epididymidis. Dense membranous whorls of MGA material (arrowed) are enmeshed in the stereocilia (Sc) abutting the lumen (L) of the epididymal duct. $\times 10,000$.

FIG. 18. Mongoose corpus epididymis. Horizontal section through the basal region of a columnar cell, showing a dense mass of MGA material in the middle of concentric arrays of smooth endoplasmic reticulum. $\times 20,000$.

\section{PLATE 6}

FIG. 19. Unstained distal caput epididymidis of rabbit. Cytoplasmic MGA material localizations at high magnification display apparent limiting membranes closely applied to their surfaces. $\times 30,000$.

Frg. 20. Unstained distal caput epididymidis of rabbit. MGA material localized in basal cells is evident as large irregularly shaped membrane-limited masses which also contain additional material not stained by malachite green. $\times 50,000$. 
types. Large, homogeneous, irregularly shaped masses were especially prevalent in the basal cells (Pl. 6, Fig. 20), and in the apical regions of the principal cells of the cauda epididymidis and ductus deferens (Pl. 4, Fig. 15). Smaller, rounded localizations were distributed throughout the cytoplasm, and were apparently not associated with any particular organelles (Pl. 6, Fig. 19). The principal cells throughout the organs contained an unusual structure lying beneath the Golgi apparatus and immediately over the nucleus; this consisted of strands of MGA material embedded in an irregularly shaped, moderately electron-dense matrix with no discernible substructure (Pl. 3, Fig. 13). Rounded masses of MGA material were also observed in close association with subnuclear concentric arrays of smooth endoplasmic reticulum (Pl. 5, Fig. 18). The MGA material was not always homogeneous, for localizations resembling myelin figures were observed in close association with the stereocilia (PI. 5, Fig. 17), and less frequently within the cytoplasm. The large, membrane-bounded masses of MGA material presumably filled vesicles which would appear 'empty' in conventionally fixed tissues; P1. 5, Fig. 16 shows MGA localizations which are distinct from and yet of similar size to other inclusions such as multivesicular bodies, clear vesicles, and vesicles containing flocculent material.

Accessory glands

The epithelium and lumen of all accessory glands were extremely rich in large masses of MGA material, as well as in other osmiophilic material not stained by malachite green (Pl. 1, Fig. 6).

\section{Effects of castration}

Preliminary results indicated that castration caused reductions in the size and frequency of MGA localizations in the principal cells and lumen of the epididymis. This was accompanied by regression of the epithelium, various degrees of loss of stereocilia, and accumulation of large masses of MGA material intermingled with other osmiophilic material in the basal cells (PI. 1, Figs 7 to 9). These lysosomal masses appeared similar to PAS-positive material observed in the caput epididymidis of rabbits following treatment with anti-androgen (Cummins \& Orgebin-Crist, 1974). The regressive changes were especially severe in the initial segment and caput epididymidis, but were not observed in control animals subjected to simple ligation of the ductuli efferentes.

\section{DISCUSSION}

The problem of the loss of cellular materials during fixation for ultrastructural studies is especially acute in the case of lipids: up to $40 \%$ of the total choline of rabbit spermatozoa is extracted during glutaraldehyde fixation (Teichman, Cummins \& Takei, 1974b) and phospholipid losses from other tissues are well documented (Morgan \& Huber, 1967; McGee-Russell \& De Bruijn, 1968; Cope \& Williams, 1968, 1969). We have already demonstrated (Teichman et al., 1972, 1974) that the fixation of rabbit spermatozoa in glutaraldehydecontaining malachite green results in the stabilization and staining of at least one glutaraldehyde-soluble phospholipid, choline plasmalogen. In the present work, the varied morphology of MGA material suggests that malachite green 
is staining a number of different classes of lipid. It also appears that the technique is acting in at least two ways; firstly, by staining and retaining glutaraldehyde-soluble lipids and, secondly, by enhancing the osmiophilia of certain lipids which are normally retained, such as Leydig cell granules. While the precise mode of action of the technique remains to be elucidated, it can nevertheless be added to the growing list of stain-fixative mixtures which are being used by electron microscopists, such as ruthenium red (Brooks, 1969; Luft, 1971a, b) and alcian blue (Behnke, 1968), for the demonstration of cell surface acid mucopolysaccharides, and digitonin for the demonstration of cholesterol (Okrös, 1968).

Despite a considerable amount of literature concerning the histochemistry of the epididymis (see reviews by Maneely, 1959; Martan, 1969; Hamilton, 1972), there is still little precise information on the localization and rôle of phospholipids in the male reproductive tract. Malachite green staining, with its specificity for fatty acids, glycolipids, phospholipids and cholesterol, promises to be a useful technique for investigating these problems. The supranuclear matrices containing strands of MGA material are of interest. Christie (1955), in a histochemical study of the mouse caput epididymidis, described "supra-nuclear bodies", in which osmiophilic and sudanophilic strands of circular bodies, frequently appearing empty, were enmeshed in a matrix containing protein and carbohydrate but no glycogen. Horstmann (1962), in an ultrastructural study of the human epididymis, described a similar "cytosomen-konglomerate". Nicander (1965) observed similar dense bodies with variable internal structure in the caput epididymidis of the rabbit, and considered them to be indicative of resorption from the epididymal lumen since they contained carbon particles after injection of india ink into the rete testis.

Our observations of masses of MGA material in close association with the smooth endoplasmic reticulum in the basal regions of the epididymal columnar cells should be considered in the light of accumulating evidence that the epididymis is a site of active synthesis of steroid hormones (Frankel \& Eik-Nes, 1968, 1970; Hamilton, Jones \& Fawcett, 1969; Hamilton \& Fawcett, 1970). Hamilton (1972) has reviewed the probable rôle of smooth endoplasmic reticulum in this function. In order to emphasize the importance of this observation, it remains only to point out that malachite green stains cholesterol as well as Leydig cell granules and granules in the adrenal cortex (authors' unpublished observations). It would be extremely valuable to compare the malachite green staining of the epididymis with ultrastructural studies using digitonin to demonstrate cholesterol (Okrös, 1968).

As already noted (Cummins \& Teichman, 1974), rabbit spermatozoa accumulate MGA material in the form of choline plasmalogen during their transit through the epididymis. A related compound, glycerylphosphorylcholine, is known to be synthesized by the epididymis of a number of species (Hamilton, 1972), and our finding of increasing amounts of luminal MGA material in progressively more distal regions of the duct is further evidence of active secretion by the organ. The ultrastructural mechanism of this secretory process is not clear, but further studies using malachite green staining are in progress. 


\section{AGKNOWLEDGMENTS}

This work was supported by grants from the U.S. Public Health Service (HD-06897, HD-03402 and HD-02066), the Ford Foundation and the Population Council. Thanks are due to Dr G. H. Takei for his assistance.

\section{REFERENGES}

BEHNKE, O. (1968) Electron microscopical observations on the surface coating of human blood platelets. 7. Ultrastruct. Res. 24, 51.

BROOKs, R. E. (1969) Ruthenium red stainable surface layer on lung alveolar cells; electron microscopic interpretation. Stain Technol. 44, 173.

Christie, A. C. (1955) A histochemical study of the cytoplasmic inclusions of the epithelial cells in the epididymis of the mouse. Q. Fl microsc. Sci. 96, 161 .

Cope, G. H. \& Williams, M. A. (1968) Quantitative studies on neutral lipid preservation in electron microscopy. 7. R. microsc. Soc. 88, 259.

COPE, G. H. \& WILLIAMS, M. A. (1969) Quantitative studies on the preservation of choline and ethanolamine phosphatides during tissue preparation for electron microscopy. I. Glutaraldehyde, osmium tetroxide, araldite methods. F. Microsc. 90, 31.

Cummins, J. M. \& OrGebin-Grist, M.-C. (1974) Effects of the anti-androgen SK \& F 7690 on the fertility of epididymal spermatozoa in the rabbit. Biol. Reprod. (in press).

Gummins, J. M. \& Teichman, R. J. (1974) The accumulation of malachite green stainable phospholipid in rabbit spermatozoa during maturation in the epididymis, and its possible role in capacitation. Biol. Reprod. 10, 555.

Frankel, A. I. \& EIK-Nes, K. B. (1968) Steroidogenesis in vitro of the epididymis of the rabbit. Fedn Proc. Fedn Am. Socs exp. Biol. 27, 624 .

Frankel, A. I. \& EIK-Nes, K. B. (1970) Metabolism of steroids in the rabbit epididymis. Endocrinology, $87,646$.

Glover, T. D. \& Nicander, L. (1971) Some aspects of structure and function in the mammalian epididymis. F. Reprod. Fert., Suppl. 13, 39.

Hamilton, D. W. (1972) The mammalian epididymis. In Reproductive Biology, p. 268. Eds. H. Balin and S. Glasser. Excerpta Medica, Amsterdam.

Hamiton, D. W. \& Fawcett, D. W. (1970) In vitro synthesis from acetate by rat epididymis and vas deferens. Proc. Soc. exp. Biol. Med. 133, 693.

Hamilton, D. W., Jones, A. L. \& FAwcett, D. W. (1969) Cholesterol biosynthesis in the mouse epididymis and ductus deferens; a biochemical and morphological study. Biol. Reprod. 1, 167.

Horstmann, E. (1962) Elektronmikroskopie des menschlichen nebenhodenepithels. Z Z Zellforsch. mikrosk. Anat. 57, 692.

LUrT, J. H. (1971a) Ruthenium red and violet. I. Chemistry, purification, methods of use for electron microscopy and mechanism of action. Anat. Rec. 171, 347.

LuFT, J. H. (1971b) Ruthenium red and violet. II. Fine structural localization in animal tissues. Anat. Rec. 171, 369.

MANEely, R. B. (1959) Epididymal structure and function: a historical and critical review. Acta zool. 40,1 .

Martan, J. (1969) Epididymal histochemistry and physiology. Biol. Reprod., Suppl. 1, 134.

McGee-Russell, S. H. \& De Bruju, W. G. (1968) Image and artifact-comments and experiments on the meaning of the image in the electron microscope. In Cell Structure and Its Interpretation, p. 115. Eds. S. H. McGee-Russell and K. F. A. Ross. Arnold, London.

Morgan, T. E. \& Huber, G. L. (1967) Loss of lipid during fixation for electron microscopy. 7. Cell Biol. 32, 757.

NiGANDER, L. (1956) On the regional histology and cytochemistry of the ductus epididymis in rabbits. Acta morph. neerl.-scand. $1,99$.

NICANDER, L. (1965) An electron microscopical study of absorbing cells in the posterior caput epididymidis of rabbits. Z. Zellforsch. 66, 829.

Nicander, L. \& Glover, T. D. (1973) Regional histology and fine structures of the epididymal duct in the golden hamster (Mesocricetus auratus). F. Anat. 113, 347.

Okrös, I. (1968) Digitonin reaction in electron microscopy. Histochemie, 13, 91.

Pearson, O. P. \& Baldwin, P. H. (1953) Reproduction and age structure of a mongoose population in Hawaii. F. Mammal. 34, 436.

Tetchman, R. J., Gummins, J. M. \& TAkeI, G. H. (1974a) The characterization of a malachite green stainable, glutaraldehyde extractable phospholipid in rabbit spermatozoa. Biol. Reprod. 10,565. 
Teichman, R. J., Cummins, R. M. \& TakeI, G. H. (1974b) The in vivo incorporation of $\left[{ }^{14} \mathrm{C}\right]-$ and $\left[{ }^{3} \mathrm{H}\right]-$ choline into phospholipids of maturing rabbit spermatozoa and reproductive tract tissues. Biol. Reprod. (in press).

Teichman, R. J., Fujimoto, M. \& Yanagimachi, R. (1972) A previously unrecognized material in mammalian spermatozoa as revealed by malachite green and pyronine. Biol. Reprod. 7, 73.

Teichman, R. J., TakeI, G. H. \& Cummins, J. M. (1974) Detection of fatty acids, fatty aldehydes, phospholipids, glycolipids and cholesterol, on thin-layer chromatograms stained with malachite green. F. Chromat. 88, 425. 